\title{
AKTIVITAS FORMULASI PESTISIDA NABATI PADA SIPUT SETENGAH TELANJANG Parmarion martensi (GASTROPODA: ARIOPHANTIDAE)
}

\author{
Sabina Sunarti Una dan Sri Wahyuni
}

Program Studi Agroteknologi Fakultas Pertanian Universitas Flores, Kampus I Jl. Sam Ratulangi XX, Paupire Kabupaten Ende Propinsi Nusa Tenggara Timur, Indonesia

\section{sriwahyuni4611@gmail.com}

\begin{abstract}
Activity of vegetable pesticides formulation in half lifestyle parmarion martens (gastropoda: ariophantidae). This study aims to determine the activity of plant-based pesticide formulations on martyred Parmarion semi-naked snails. The study conducted at the Laboratory of the Faculty of Agriculture, University of Flores, Sam Ratulangi Street, Ende Regency. The research was conducted from February to August 2019 using a Completely Randomized Design (CRD) with two stages of treatment. The first stage was testing the contact poison activity in 5 treatments namely $\mathrm{P} 0=$ Control, $\mathrm{P} 1=$ Dilution $1: 5$, $\mathrm{P} 2=$ Dilution 1:10, P3 = Dilution 1:15, P4 = Pure extract. The second step is to test the stomach poison with five treatments namely $\mathrm{R} 0=$ Control, $\mathrm{R} 1=$ No immersion, $\mathrm{R} 2=$ Soak 10 minutes, $\mathrm{R} 3=$ Soak 20 minutes, $\mathrm{R} 4=$ Soak 30 minutes. All treatments are repeated five times so that they will get 25 units of experiments in every treatment. The results showed the concentration of vegetable pesticide extracts in contact poisons and stomach poisons the highest average mortality for contact poisons were found in $\mathrm{P} 4$ therapy with the highest mortality value of $68.00 \%$ and experienced the fastest death above $50.00 \%$ at 50.80 hours with single speed time is 0.55 hours. While the stomach poison in the $\mathrm{R} 4$ treatment is $66.66 \%$ with the time, the fastest mortality is above $50.00 \%$, which is 55.40 hours with a speed of 0.57 hours per individual.
\end{abstract}

Keywords: Activity, Botanical Pesticides, Formulation

\section{PENDAHULUAN}

Pestisida merupakan bahan yang dianggap paling ampuh untuk mengendalikan organisme pengganggu tumbuhan (OPT). Petani masih mengandalkan penggunaan pestisida sintetis (non nabati) dalam mengendalikan hama tanaman dengan alasan mudah didapat dan efektif, walaupun banyak menimbulkan dampak negatif terhadap lingkungan (Kardinan, 1998). Oleh sebab itu, banyak peneliti yang 
mengembangakan pestisida ramah lingkungan yaitu pestisida nabati. Indonesia merupakan wilayah beriklim tropis dengan keunggulan sumber daya hayatinya (biodiversity). Jenis tumbuhan yang ada di Indonesia dan berpotensi sebagai pestisida nabati sebanyak 2.400 jenis tumbuhan yang termasuk ke dalam 235 famili (Asmaliyah et al., 2010). Tumbuhan yang menghasilkan metabolit sekunder dapat digunakan sebagai bahan aktif pestisida nabati (Kardinan, 2011). Bahan- bahan ini diolah menjadi berbagai bentuk, antara lain bahan mentah berbentuk tepung, ekstrak atau resin yang merupakan hasil pengambilan cairan metabolit sekunder dari bagian tumbuhan atau bagian tumbuhan dibakar untuk diambil abunya dan digunakan sebagai pestisida (Subiyakto, 2009; Tohir dan Ali, 2010).

Beberapa tanaman yang memiliki senyawa aktif pestisida nabati dan mudah ditemukan diantaranya adalah daun sirsak (Annona muricata L.) yang memilki senyawa tanin, fitosterol, ca-oksalatclan, alkaloid dan murisine. Kandungan senyawa ini bersifat insektisida. Konsentrasi tinggi pada kandungan senyawa sirsak juga dapat menolak (Repellent) atau dapat menghambat aktivitas makanan (Antifeedant). Sedangkan konsentrasi rendah bersifat racun perut yang bisa mengakibatkan serangga hama menyebabkan kematian (Septerina, 2002). Krinyuh (Chromolaena odorata L) memiliki kandungan senyawa seperti tannin, fenol, flavonoid, saponin dan steroid (Hadi et al., 2000) senyawa- senyawa ini merupakan bahan aktif yang dapat mengendali hama dan menyebabkan adanya aktivitas penghambatan makan (Antifeedant). Rimpang lengkuas (Alpinia galangal L) memiliki kandungan kimia, yakni saponin, tannin, flavonoida, minyak atsiri, sedangkan pada batang yaitu saponin, tanin dan flavonoida (Anonimous, 2009) senyawa-senyawa tersebut merupakan bahan aktif yang dapat menyebabkan aktivitas biologi hama mengalami penghambatan makan (Antifeedant) dan insektisida. Serai (Andropogon citrates L), memiliki kandungan minyak atsiri. Serai terdiri dari senyawa sitral, sitronela, geraniol, mirsena, nerol, farnesol methyl heptenol dan dipentena. Kandungan yang paling besar adalah sitronela yaitu sebesar 35\% dan graniol sebesar $35-40 \%$. Senyawa sitronela ini bersifat racun dehidrasi (desiccant), racun ini merupakan racun kontak yang dapat mengakibatkan kematian karena hilangnya cairan secara terus menerus. Sehingga hama atau serangga yang terkena racun ini akan mati karena kekurangan cairan, pada hama tertentu serai juga mengeluarkan aroma yang memiliki efek menarik (attractan) karena bersifat insektisida, bakterisida dan nematisida. Keempat jenis tanaman tersebut dapat digunakan secara tunggal ataupun dapat dicampur sebagai bahan pestisida untuk mengendalikan Organisme Pengganggu Tanaman (OPT) di areal pertanaman.

Salah satu jenis hama polifag yang mampu merusak berbagai jenis tanaman seperti pada famili Cucurbitaceae, 
Brassicaceae, Asteraceae, Araceae adalah Parmarion martensi (Gastropoda: Ariophantidae) atau yang sering disebut sebagai siput setengah telanjang. Laporan kerusakan akibat serangan $P$. martensi diketahui dari penelitian Apriyanto (2003) yang menyatakan bahwa keberadaan $P$. martensi 5 ekor pertanaman kubis dapat menyebabkan kerusakan sebesar $50 \%$. Sementara itu, Rahayu (2000) juga melaporkan kerusakan $P$. martensi pada tanaman sayuran, tembakau dan anggrek di Jawa Tengah dapat mencapai 1,5 ha per musim tanam, melihat potensi merusak $P$. martensi pada beberapa hasil penelitian maka $P$. martensi dijadikan sebagai bahan uji pada penelitian ini.

\section{METODE PENELITIAN}

Tempat dan Waktu

Penelitian dilaksanakan di Laboratorium Fakultas Pertanian Universitas Flores, Jln Sam Ratulangi XX Paupire-Kabupaten Ende selama 7 bulan.

\section{Bahan dan Alat}

Bahan yang digunakan adalah daun sirsak (Annona muricataL.), daun kirinyuh (Chromolaena odorata L.), serai (Andropogon citrates L), rimpang lengkuas (Alphiniagalanga L), siput setengah telanjang (Parmarion martensi), batang talas, air dan kertas label. Peralatan yang digunakan dalam penelitian adalah timbangan analitik, pipet tetes, pinset, spatula, gelas ukur, batang pengaduk, toples, pisau, papan cincang, kertas saring, ember dan spoit.

\section{Rancangan Percobaan}

Penelitian ini menggunakan Rancangan Acak Lengkap (RAL) dengan, 2 tahap perlakuan yaitu tahap pertama menguji aktivitas racun kontak pada 5 perlakuan yaitu $\mathrm{P} 0=$ Kontrol, $\mathrm{P} 1=$ Pengenceran 1:5, P2 = Pengenceran 1:10, $\mathrm{P} 3=$ Pengenceran 1:15, P4 = Ekstrak murni. Tahap kedua dengan menguji racun perut dengan 5 perlakuan yaitu $\mathrm{R} 0=$ Kontrol, R1 = Tanpa perendaman , R2 = Rendam 10 menit, R3 = Rendam 20 menit, $\mathrm{R} 4$ = Rendam 30 menit, semua perlakuan diulang selama 5 kali sehingga akan memperoleh 25 unit percobaan dalam setiap perlakuan.

\section{Parameter Pengamatan}

1. Mortalitas Racun kontak dan Racun perut (\%)

Racun kontak adalah cara kerja pestisida yang masuk ke dalam tubuh $P$. martensi melalui kulit, trakea atau langsung mengenai mulut Parmarion martensi dan menyebabkan kematian apabila bersinggung langsung dengan pestisida tersebut (Anonim, 2010), sedangkan pestisida membunuh $P$. martensi melalui salur pencernaan makanan (perut) apabila pestisida tersebut termakan $P$. martensi lewat makanan (Untung, 2006). Mortalitas pada kedua jenis uji aktivitas tersebut dihitung berdasarkan rumus yang digunakan oleh Fagoone dan Lauge (1981) dan Sinaga (2009) sebagai berikut :

$$
M=\frac{b}{a+b} \times 100
$$


Keterangan :

$\mathrm{M}=$ Mortalitas $(\%)$

$\mathrm{a}=$ Bahan uji ( $P$. martensi $)$ yang hidup

$\mathrm{b}=$ Bahan uji yang mati

2. Lethal time (LT) 50 dan waktu kecepatan kematian

Dihitung mulai dari saat pemberian pestisida nabati hingga $P$. martensi mengalami mortalitas di atas 50\% (jam). Waktu kecepatan dihitung dengan menggunakan rumus menurut Fagoone dan Lauge (1981) dalam Sinaga (2009) berikut :

$\mathrm{V}=\frac{\mathrm{T} 1 \mathrm{~N} 1+\mathrm{T} 2 \mathrm{~N} 2+\mathrm{T} 3 \mathrm{~N} 3 \ldots . \mathrm{TnNn}}{\mathrm{n}}$

Keterangan:

V : Kecepatan Kematian (Jam/ekor)

$\mathrm{T}$ : Waktu Pengamatan ( Jam)

$\mathrm{N}$ : Jumlah bahan uji yang mati (Ekor)

$\mathrm{n}$ : Jumlah seluruh bahan uji (Ekor)

\section{Atractan dan Aktivitas Makan}

Diamati mulai saat pemberian pakan, yang telah diaplikasikan pestisida nabati untuk membuktikan aktivitas hama adalah ketergantungan Parmarion martensi pada pakan. Indikasi aktivitas pestisida nabati sebagai attractan ditandai dengan kesukaan atau mendekatnya $P$. martensi pada pakan sementara itu perubahan perilaku juga diamati.

\section{Pelaksanaan Penelitian}

\section{Pembuatan pestisida nabati}

Teknik pembuatan pestisida nabati diuraikan sebagai berikut: Semua bahanbahan seperti daun sirsak, kriyu, lengkuas dan serai dicincang dan ditimbang masing-masing 250 gram. Selanjutnya bahan-bahan tersebut blender hingga halus kemudian dicampur dengan air sebanyak 1 liter di dalam ember dan didiamkan selama 24 jam. Selanjutnya larutan disaring dan siap untuk diaplikasikan pada $P$. martensi sesuai dengan perlakuan.

\section{Persiapan Parmarion martensi sebagai bahan uji \\ Parmarion martensi yang akan dijadikan bahan uji diseleksi berdasarkan ukuran yang seragam, untuk etiap perlakuan akan membutuhkan sebanyak 50 ekor.}

\section{Aplikasi perlakuan}

1. Aplikasi Racun kontak: Larutan pestisida nabati diencerkan sesuai perlakuan dengan menggunakan air (kontrol), P1 (pengenceran 1:5), P2 (pengenceran 1:10), P3 (pengenceran 1:15) dan P5 (ekstrak murni). Selanjutnya $P$. martensi dimasukan ke dalam toples sebanyak 5 ekor dan diberikan perlakuan sebanyak 0,5 ml/ekor dengan cara disemprotkan langsung pada tubuh $P$. martensi dan diulang sebanyak 5 kali. Pemberian pakan tetap dilakukan dan diganti setiap hari. Pengamatan dilakukan mulai pada saat pemberian perlakuan untuk melihat perubahan perilaku $P$. martensi setelah aplikasi. Pengamatan dilakukan setiap 3 jam sekali selama 3 hari. Mortalitas dihitung mulai hari pertama sampai hari ketiga.

2. Aplikasi racun perut dapat diuraikan sebagi berikut: $P$. martensi sebagai bahan uji dipuasakan selama 24 jam 
sebelum perlakuan. Larutan pestisida nabati diencerkan dengan perbandingan 1:5 untuk merendam pakan yang akan diberikan pada $P$. martensi sesuai perlakuan R0 (kontrol), R1 (tanpa perendaman), R2 (rendam 10 menit), R3 (rendam 20 menit), R4 (rendam 30 menit ). P.martensi dimasukan ke dalam toples sebanyak 5 ekor bersama dengan pakan yang sudah diberikan. Pengamatan dilakukan mulai pada saat pemberian perlakuan untuk melihat perubahan perilaku $P$. martensi setelah aplikasi dan melihat apakah dia bersifat atractan atau repelant. Pengamatan dilakukan mulai pada saat pemberian perlakuan untuk melihat perubahan perilaku $P$. martensi setelah aplikasi. Mortalitas dihitung mulai hari pertama sampai hari ketiga.

3. Atraktan, Repelant dan Perilaku Makan: Pengamatan dimulai pada saat $P$. martensi dimasukan ke dalam toples yang sudah tersedia pakan sesuai perlakuan. Jika $P$. martensi menghindar dari pakan tersebut maka $P$. martensi bersifat repelan sedangkan jika $P$. martensi mendekat ke pakan maka P.martensi bersifat atraktan.

\section{Analisis Data}

Data hasil pengamatan dianalisis dengan analisis sidik ragam, dengan rancangan yang digunakan. Apabila perlakuan berpengaruh nyata terhadap variabel yang diamati, maka dilanjutkan dengan uji BNT 5\% (Gomez dan Gomez, 1995).

\section{HASIL DAN PEMBAHASAN Aktivitas Racun Kontak}

Parmarion martensi yang diberi perlakuan dengan cara meneteskan ekstrak secara langsung ketubuh memperlihatkan reaksi dengan dihasilkannya lendir berlebih dan berwarna putih selanjutnya setelah 3 jam $P$. martensi mulai lemas, tidak bergerak dan hanya menetap pada satu tempat, kematian dimulai pada 24 jam. Kematian ditandai dengan $P$. martensi mengeluarkan lendir hitam dan cangkang sudah tidak nampak. $P$. martensi yang mati dengan cara membalik tubuhnya, menyembunyikan cangkangnya dan mengeluarkan kotoran berwarna hitam dan mengeluarkan aroma amis yang menyengat. Kondisi yang demikian diperkirakan karena adanya kandungan senyawa sitronela pada larutan yang bersifat racun dan menimbulkan efek dehidrasi (desiccant) racun ini merupakan racun kontak yang dapat mengakibatkan kematian karena hilangnya cairan secara terus menerus.

Analisis sidik ragam aktivitas racun kontak pada $P$. martensi menunjukkan pengaruh yang sangat nyata dibandingkan dengan kontrol, tetapi tidak berbeda nyata antara P1, P2, P3, P4. Hal ini dapat dilihat pada pengamatan setiap 3 jam sekali selama 3 hari (Tabel 1).

Tabel 1 memperlihatkan bahwa perlakuan P0 (kontrol) tidak berpengaruh pada P.martensi dikarenakan air tidak mengandung zat yang dapat mematikan, air hanya berfungsi sebagi zat pelarut. Rataan persentase mortalitas tertinggi terjadi pada perlakuan P4 yaitu sebesar 
68.00\%. Secara logika semakin tinggi konsentrasi bahan aktif suatu senyawa, maka jumlah bahan bahan aktif yang bersifat racun lebih banyak dan bekerja lebih evektif, sehingga dapat menghambat

Tabel 1 Rata- rata persentase Mortalitas Racun kontak hama P.martensi setiap 24 jam

\begin{tabular}{ccccc}
\hline \multirow{2}{*}{ Perlakuan } & \multirow{2}{*}{$\mathrm{N}$} & \multicolumn{3}{c}{ Presentase Mortalitas Racun Kontak Parmarion martensi (\%) } \\
\cline { 3 - 5 } & & $24 \mathrm{Jam}$ & $48 \mathrm{Jam}$ & $72 \mathrm{Jam}$ \\
\hline P0 & 5 & $0.00 \mathrm{c}$ & $0.00 \mathrm{~d}$ & $0.00 \mathrm{~b}$ \\
P1 & 5 & $12.00 \mathrm{ab}$ & $36.00 \mathrm{ab}$ & $20.00 \mathrm{a}$ \\
P2 & 5 & $8.00 \mathrm{bc}$ & $16.00 \mathrm{bc}$ & $28.00 \mathrm{a}$ \\
P3 & 5 & $4.00 \mathrm{bc}$ & $8.00 \mathrm{~cd}$ & $20.00 \mathrm{a}$ \\
P4 & 5 & $20.00 \mathrm{a}$ & $36.00 \mathrm{a}$ & $36.00 \mathrm{a}$ \\
\hline BNT 5\% & & $\mathbf{3 , 3 9}$ & 3,36 & 4,19
\end{tabular}

Keterangan: Angka-angka yang diikuti huruf yang sama pada kolom yang sama, berarti tidak berbeda nyata pada uji BNT taraf 5\%. Data ditransformasi dengan menggunakan Arcsi $\sqrt{ } \mathrm{x}$.

\section{Aktifitas Racun Perut, Atraktan dan Perilaku Makan}

Reaksi $P$. martensi yang perlakuan adalah tertarik dan mendekati pakan yang diikuti dengan aktifitas makan sesaat setelah pemberian pakan di lakukan. Efek perubahan perilaku pada $P$. martensi adalah lemas, mati atau tidak bergerak sama sekali banyak mengeluarkan lendir berwarna putih hingga hitam hal ini karena di dalam serai mengandung senyawa aktif sitronela yang paling besar yaitu 35\% dan graniol sebesar 35\%-40\%. Senyawa sitronela bersifat menarik (atractan) (Septerina, 2002). Senyawa aktif yang terkandung pada insektisida nabati akan mengganggu sistem saraf dan menimbulkan reaksi ketertarikan $P$. martensi pada pakan, sementara itu di dalam tubuh $P$. martensi pestisida pertumbuhan dan menyebabkan kematian bahan uji lebih banyak (Sutoyo dan Wirioadmojo, 1997). 
direndam dengan menggunakan ekstrak pestisida selama 30 menit. Menurut Endah dan Heri dalam Sinaga (2009) bahwa fungsi dari alkaloid, triterpenoid, saponim, dan glikosida flavonoid yang ada di dalam daun sirsak, kriyuh, serai dan lengkuas dapat menghambat daya makan serangga.
Senyawa-senyawa tersebut bertindak sebagai stomach poisoning atau racun perut. Karena itu apabila senyawasenyawa masuk di dalam tubuh serangga maka akan mengganggu saluran pencernaan.

Tabel 2 Rata- rata persentase Mortalitas Racun Perut hama P.martensi

\begin{tabular}{ccccc}
\hline \multirow{2}{*}{ Perlakuan } & \multirow{2}{*}{} & Presentase Mortalitas & Racun Kontak Parmarion martensi (\%) \\
\cline { 3 - 5 } & 5 & $0.00 \mathrm{~b}$ & $48 \mathrm{Jam}$ & $72 \mathrm{Jam}$ \\
\hline R0 & 5 & $8.00 \mathrm{~b}$ & $0.00 \mathrm{~b}$ & $0.00 \mathrm{c}$ \\
R1 & 5 & $12.00 \mathrm{ab}$ & $16.00 \mathrm{ab}$ & $16.00 \mathrm{bc}$ \\
R2 & $16.00 \mathrm{ab}$ & $24.00 \mathrm{a}$ & $20.00 \mathrm{abc}$ \\
R3 & 5 & $24.00 \mathrm{a}$ & $32.00 \mathrm{a}$ & $28.00 \mathrm{ab}$ \\
R4 & 5 & 3,88 & 4,23 & $32.00 \mathrm{a}$ \\
\hline BNT & & &
\end{tabular}

Keterangan: Angka-angka yang diikuti huruf yang sama pada kolom yang sama, berarti tidak berbeda nyata pada uji BNT taraf 5\%. Data ditransformasi dengan menggunakan Arcsi $\sqrt{\mathrm{x}}$.

\subsection{Lethal Time dan Kecepatan Waktu Kematian / Individu}

Hasil pengamatan lethal time (LT 50

$\%$ ) racun perut dan racun kontak setelah dianalisis menggunakan sidik ragam menunjukan bahwa perlakuan konsentrasi ekstrak pestisida nabati memberikan pengaruh yang sangat nyata terhadap waktu yang dibutuhkan ekstrak pestisida untuk mematikan hama Parmarion martensi, hasil uji BNT taraf 5\% dapat dilihat pada Tabel 3.

Dari hasil analisis sidik ragam pada Tabel 3 menunjukkan bahwa pada konsentrasi ekstrak pestisida nabati pada perlakuan racun kontak $\mathrm{P} 4$ berbeda sangat nyata dengan perlakuan P3, P2, P0 dan berbeda nyata pada konsentrasi ekstrak pestisida nabati pada perlakuan P1. Hal yang demikian juga di jelaskan pada mortalitas racun perut di mana perlakuan R4 dan R3, berbeda nyata dengan R2 dan berbeda sangat nyata pada R1 dan R0. Hal ini di perkuatkan oleh Dewi (2010) menyatakan bahwa konsentrasi ekstrak yang lebih tinggi maka pengaruh yang ditimbulkan semakin tinggi, disamping itu daya kerja suatu senyawa sangat ditentukan oleh besarnya kosentrasi. Semakin tinggi kosentrasi yang diberikan maka akan semakin tinggi kemampuan bahan aktif untuk mematikan bahan uji. 
Tabel 3 Mortalitas racun perut dan racun kontak pada hama P.martensi (LT 50) dengan perlakuan beberapa konsentrasi ekstrak pestisida nabati (jam) dan kecepatan waktu.

\begin{tabular}{|c|c|c|c|}
\hline Perlakuan & $\begin{array}{l}\text { Mortalitas (\%) } \\
\text { Racun Kontak }\end{array}$ & $\begin{array}{c}\text { Lethal Time }(50 \%) \text { jam } \\
\text { Racun Kontak }\end{array}$ & $\begin{array}{c}\text { Kecepatan } \\
\text { waktu / individu (Jam/ekor) }\end{array}$ \\
\hline $\mathrm{P} 0$ & $0.00 \mathrm{c}$ & $72.00 \mathrm{a}$ & 0 \\
\hline $\mathrm{P} 1$ & $68.00 \mathrm{ab}$ & $53.00 \mathrm{~d}$ & 0,77 \\
\hline $\mathrm{P} 2$ & $52.00 \mathrm{bc}$ & $58.80 \mathrm{~b}$ & 1,13 \\
\hline P3 & $32.00 \mathrm{c}$ & $60.00 \mathrm{~b}$ & 1,87 \\
\hline $\mathrm{P} 4$ & $92.00 \mathrm{a}$ & $50.80 \mathrm{e}$ & 0,55 \\
\hline BNT $5 \%$ & 3,25 & 1,37 & \\
\hline \multirow{2}{*}{ Perlakuan } & Mortalitas (\%) & Lethal Time $(50 \%)$ jam & Kecepatan \\
\hline & Racun Perut & Racun perut & Waktu/ idividu (Jam/ekor) \\
\hline R0 & $0.00 \mathrm{c}$ & $72.00 \mathrm{a}$ & 0 \\
\hline $\mathrm{R} 1$ & $36.00 \mathrm{~b}$ & $62.00 \mathrm{~b}$ & 1,72 \\
\hline $\mathrm{R} 2$ & $52.00 \mathrm{ab}$ & $58.80 \mathrm{c}$ & 1,13 \\
\hline R3 & $76.00 \mathrm{a}$ & $57.60 \mathrm{c}$ & 0,75 \\
\hline /R4 & $96.00 \mathrm{a}$ & $55.40 \mathrm{e}$ & 0,57 \\
\hline BNT $5 \%$ & 3,25 & 3,06 & \\
\hline
\end{tabular}

Keterangan: Angka-angka yang diikuti huruf yang sama pada kolom yang sama, berarti tidak berbeda nyata pada uji BNT taraf $5 \%$. Data ditransformasi dengan menggunakan Arcsi $\sqrt{ } \mathrm{x}$.

Pemberian pestisida nabati perendaman pakan yang paling lama, terhadap $P$. martensi pada variabel dimana pakan tersebut direndam pengamatan racun kontak yang tertinggi menggunakan ekstrak pestisida dengan terdapat pada perlakuan P4 dengan nilai konsentrasi perbandingan 1:5. Hal ini mortalitas $92 \%$ dan mengalami mortalitas membuktikan pengujian residu pakan paling cepat diatas $50 \%$ pada jam ke sangat dipengaruhi oleh lamanya waktu 50,80 degan waktu kecepatan individu perendaman, semakin lama pakan 0,55 jam. Hal ini terjadi karena P4 dicelupkan dalam pestisida maka semakin merupakan ekstrak murni pestisida nabati banyak residu yang menempel pada pakan dimana mengandung zat-zat beracun salah dan menyebabkan hama yang memakan satunya bersifat dehidrasi. Semantara pada racun perut yang tertinggi pada perlakuan R4 dengan nilai mortalitas 96\% dan mengalami mortalitas paling cepat diatas $50 \%$ yaitu pada jam 55,40 degan waktu kecepatan individu 0,57 jam. Hal ini sebabkan karena R4 merupakan pakan tersebut keracunan. Hal ini disebabkan pestisida dalam pakan berdifusi atau terjadi release sebelum hama memakan pakan tersebut. Hal ini didukung oleh pendapat Trizelia (2001), bahwa residu pestisida berkurang menyebabkan aktivitas makanan serangga 
menurun, bahkan tidak ada hama uji yang mati.

\section{SIMPULAN}

Ekstrak pestisida nabati dari bahan kriyu, sirsak, serai, dan lengkus memiliki aktivitas sebagai racun kontak, racun perut dan bersifat atraktan dengan mortalitas tertinggi pada racun kontak adalah $68,00 \%$ (P4) dengan lethal time diatas $50 \%$ terjadi pada jam ke 50,80 dengan kecepatan waktu per individu 0,55 jam. Mortalitas Racun perut tertinggi pada perlakuan R4 dengan nilai mortalitas $66,66 \%$ dan mengalami mortalitas paling cepat di atas $50 \%$ yaitu pada jam 55,40 dengan waktu kecepatan per individu adalah 0,57 jam.

\section{UCAPAN TERIMAKASIH}

Pada kesempatan ini, penulis mengucapkan terimakasih yang sebesarbesarnya kepada semua pihak yang telah mendukung pelaksanaan penelitian ini baik dari pihak lembaga, lingkungan, lembaga pendidikan Universitas Flores. Semoga Tuhan Yang Maha Esa memberikan berkahnya kepada kita semua.

\section{DAFTAR PUSTAKA}

Asmaliyah., Etik E.W. H., Utami S, Kusdi, Mulyadi, Yudhistira, Fitri W.S. 2010. Pengenalan Tumbuhan Penghasil Pestisida Nabati dan Pemanfaatannya Secara Tradisional. Kemenhut. Badan Penelitian dan Pengembangan Kehutanan. Pusat
Penelitian dan Pengembangan Produktifitas Hutan

Apriyanto, D. 2003. Koinsidensi 2 spesies respo di sentra produksi sayur Rejang Lebong Bengkulu. JIPI. 5(1):7-11

Anonim, 2010. Cara Kerja Insektisida. 30 Januari 2011.

Anonimus , 2009. Kailan. Http://bangkittani.com/ kiat- sukses Itanaman -kailan- digemariwisatawan- mancanegara

Anonimus, 2005. Pestida Organik .Http://www. Deptan. Qo.id/ditlinhorti/buku/no kimia.id/php. 2 hal

Brower J.E., Zar J, Von E.C. 1997. Field and Laboratory Methods for General Ecology. London (GB): Brown Pub

Fagoone dan Lauge 1981 . Analisis Tingkat Kematian Hama Jakarta: Erlangga

Clement D.L., May L. 2002. Slugs \& Snails. Eastern Shore (US): Maryland Cooperative extension

Grainge, M. And Ahmed S. 1998. Handbook of plants with PestControl Properties. Jhon Wiley and Son, New York- ChichesterBrisbane-Toronto Singapore. Pp.99153 
Gomez,K.A.,Gomez,A.A.A.1995.Prosedu

r Statistik untuk Penelitian

Pertanian. Universitas Indonesia (terjemahan,.Jakarta.

Hadi, M., Hidayat, J.W., Baskoro K. 2000. Uji Potensi Ekstrak Daun Eupartorium odoratum sebagai Bahan Insektisida Alternatif: Toksisitas dan Efek Antimakan Terhadap Larva Heliothis armigera Hubner. Jurnal Sains dan Matematika. Fakultas MIPA Undip. Semarang.

Hadi, M. 2002. Pembuatan kertas anti rayap ramah lingkungan dengan memanfaatkan ekstrak daun kriyuh ( Eupatorium odoratum). Bioma 6(2) : 1218

Hooks, C.R., Hinds J. 2009. Managing Slugs in the Garden and Beyond. Easten Shore (US): University of Maryland Cooperative Extension Entomology.

Isnaningsih, N.R. 2008. Siput telanjang (slug) sebagai hama tanaman budidaya. Fauna Indonesia. $8(2): 21-24$

Kardinan, A. 1998. Prospek penggunaan pestisida nabati di Indonesia. Jurnal Litbang Pertanian 17(1): 1 8. Laba, I W., D. Kilin, dan D. Soetopo. 1998. Dampak penggunaan insektisida dalam pengendalian hama. Jurnal Litbang Pertanian 17(3): 99-107.
Kardinan, A. 2011.Penggunaan Pestisida Nabati Sebagai Kearifan Lokal dalam Pengendalian Hama Tanaman Menuju Sistem Pertanian Organik. Pengembangan Inovasi Pertanian 4(4) : 262-278

Kardina, A 2011. Penggunaan pestisida nabati sebagai kearifan lokal dalam mengendalikan hama tanaman manuju sistem pertanian organik. Pengembangan Inovasi Pertanian04(4):262-278.

Kardinan, A. 2002. Pestisida Nabati, Ramuan dan Aplikasi. Jakarta:Penebar Swadaya

Kalshoven L.G.E. 1981. Pest of Crop in Indonesia. Loan PA, penerjemah; Hoeve IB. Jakarta (ID): Van Der.

Rahayu, B., Indarti S, Harjaka T. 2000. Beberapa catatan mengenai hama baru : penggulung daun teh siput setengah telanjang, Parmarion martensi . Jurnal Perlindungan Tanaman. 6(1):61-64.

Subiyakto, dan Sunarto, A. D. 1999. Insektisida Nabati Sebagai Alternatif Pengendalian Serangga Hama Utama Tembakau. Prosiding Semiloka

Subiyakto , 2009. Ekstrak biji mimba sebagai pestisida nabati :Potensi, kendala, dan strategi pengembanganya.Jurnal Perspektif 8(2): 108-116 
Septerina, 2002. Pengaruh ekstrak sebagai insektisida Rasional Terhadap Pertumbuhan dan Hasil Tanaman Paprika Varietas Bell Boy.Tesis S-2 Fakultas Pertanian. Universitas Muhamaddiah. Malang

Seterina, N. J. 2002. Pengaruh Ekstrak Daun Sirsak Sebagai Insektisida Rasional terhadap Pertumbuhan dan Hasil Tanaman Paprika Varietas Bellboy. Digilib. itb.ac.id/gdi. php?modbrowse \&op:read\& jd;jitown-gdi-SI-2002niken-5526ekstrak
Untung, K. 2006. Pengantar Pengelolaan Hama Terpadu. Yogyakarta: UGM press.

Zarkani, A. 2008. Aktifitas Insektisida Ekstrak Piper retrofractum Vahl. dan Tephrosia vogelii Hook. F. terhadap Crocidolomia pavonana (F) dan Plutella xylostella (LO) serta Keamanan Ekstrak tersebut terhadap Diadegma semiclausum (Hellen). Skripsi (Tidak dipublikasikan). Institut Pertanian Bogor. 